\title{
Developing organizational knowledge in schools: The role of theory and theorizing in collective capacity building
}

\author{
Turid I. Ertsås ${ }^{1}$ Eirik J. Irgens ${ }^{1}$ (])
}

Accepted: 22 June 2021 / Published online: 20 July 2021

(c) The Author(s) 2021

\begin{abstract}
Developing knowledge in education systems is essential in capacity building. When the intention is to build collective capacity and sustain the capacity in schools, we claim there is a need to understand how organizational knowledge is developed and what form this knowledge may take in the school as an organization. However, theory seems to have put little weight on the development of organizational knowledge. In this article, we draw on two cases to discuss why there is a need for theoretical perspectives that may help conceptualize and aid knowledge development in capacity building. Our contribution is a theoretical model that builds on a graded theory concept, in which theory and practice are understood as entangled in process rather than as dichotomous and static categories. We hope to contribute to an understanding of capacity building that avoids the tyranny of theory and the tyranny of practice, and where teachers' and school leaders' professional theorizing is seen as essential for success.
\end{abstract}

Keywords Theory $\cdot$ Capacity building $\cdot$ Knowledge development $\cdot$ Professional theorizing $\cdot$ Educational change $\cdot$ School development $\cdot$ Organizational learning

\section{Introduction}

A decade after Rutter et al. (1979) found that some school organizations influence students more than others, and Argyris and Schön (1978) helped establishing organizational learning as a field of study, we saw the beginning of a series of studies that pointed to the importance of teacher collaboration and collective and organizational learning in schools (e.g., DuFour \& Eaker, 1998; Kruse et al., 1994; Leithwood et al., 1995). The production of articles and books continued after the

Eirik J. Irgens

eirik.j.irgens@ntnu.no

Turid I. Ertsås

Turid.ertsas@ntnu.no

$1 \quad$ NTNU, 7491 Trondheim, Norway 
millennium (e.g., Bryk et al., 2010; Hargreaves \& Fullan, 2012; Harris, 2011; Stoll $\&$ Kools, 2017). Although organizational learning had already become a field and a direction in the organization literature (Dodgson, 1993), the new series of publications now addressed schools more explicitly, and contributed to, among other, an increased interest in professional learning communities and the school as a learning organization.

Making schools learning organizations became pressing for the Norwegian government when the results from comparisons of national educational systems in Europe were published in 2001 by OECD, the Organization for Economic Cooperation and Development. Norwegian politicians were disappointed: Norway was among the nations with the highest educational expenditure, but the schools had not lived up to what was expected. A series of government-initiated and governmentfunded nation-wide educational change programs followed. However, in a 2017 white paper, and after spending a substantial amount of money, the ministry concluded that the programs had not succeeded in securing local anchoring and involvement (Ministry of Education and Research, 2017).

Some of the questions that have motivated our research are therefore: How can we increase the likelihood that the school as an organization, and not only individual teachers, learn when programs are initiated in order to build collective capacity? What can impede the new knowledge from leading to widespread and lasting improvements in teaching and forms of collaboration? How can theoretical perspectives help conceptualize and aid knowledge development in capacity building and increase the probability that we achieve improvements all the way into the classroom?

On this background, our overriding research question is: How can we understand how knowledge is developed in schools participating in capacity building programs, and what form this knowledge may take in the school as an organization?

\section{Background}

After what has been known as the "PISA"-chock in 2001, the Norwegian ministry called for a change of culture and the ways schools organized work: "If we are to succeed, the school has to become a learning organization," the Ministry argued (Ministry of Education \& Research, 2004, p. 3). The call for Norwegian schools to become learning organizations was repeated in white papers in the years to come, and on a global level, OECD issued a "practical guidance on how schools can transform themselves into a learning organization and ultimately enhance student outcome" (Kools \& Stoll, 2016) as well as s guide for policy makers, school leaders and teachers named «What makes a school a learning organisation?» (Organization for Economic Cooperation and Development [OECD], 2016).

Collective capacity, collaborative cultures, culture for learning, and professional capital were now central topics, as became evident when Hargreaves and Fullan summed up this new strand of research by concluding that successful schools were a result of a whole school, profession, and system effort (Hargreaves $\&$ Fullan, 2012). DuFour and Fullan followed up by concluding that the evidence 
was quite strong that the fundamental structure in schools should not be an educator but a collaborating team. No teacher should be allowed to work in isolation (DuFour \& Fullan, 2013, p. 40). The Organization for Economic Cooperation and Development (OECD), a strong influencer on national educational policies (Moos, 2013), has likewise stressed the importance of developing schools into learning organizations (Kools \& Stoll, 2016; OECD, 2016; Stoll \& Kools, 2017).

The focus on nations as education systems seems to have increased after the millennium change, partially due to the role of OECD (see for example Moos, 2013; Shirley, 2016). Education research influences education policies, jargon, and practice, and some research has fostered powerful ideas that acquire the status of "global education policies" as they travel between nations (Verger et al., 2012). Norway may serve as an interesting example, because for more than 10 years, the Norwegian government and the Directorate of Education have taken a very active role in increasing the quality of schools. A series of governmentinitiated and government-funded system-wide educational change programs has been launched (Irgens, 2017). The majority of these programs have been aimed at developing collective capacity based on competence strategies, ranging from traditional 1-2-day out-of-school courses and seminars for individual teachers to school-based programs attended by all teachers and leaders. However, several evaluation reports have expressed concerns about the actual effect of these programs on schools, and how lasting the effects are (Dehlin \& Author2, 2017; Ministry of Education and Research, 2017).

In this article, we will use two nation-wide educational change programs as cases to discuss the role of theory in developing the collective capacity of schools, understood as the "knowledge-building process, intended to lead to increased student achievement in every school" (Sharrat \& Fullan, 2009, p. 8). Both programs aimed at building capacity to improve education practices in schools, and both programs aimed at developing not only individual teachers' knowledge but also the whole school's shared knowledge through individual and organizational learning. We direct attention to how organizational knowledge may be produced as a result of competence development or to be more specific, how participation in courses and other competence measures may lead not only to professional development at the individual level but also to school development and improvements that last.

To do so, we present a graded theory model that builds on two of Kolb's central ideas: transformation and the development of theory to be tested in practice (Kolb, 1976, 1984). To reduce the tendencies in the Kolb tradition to present processes as distinct sequences (see Kolb, 1984, p. 33) and to bring in the role of generic theory, we apply a graded theory concept (Ertsås \& Irgens, 2016), where we direct attention to theorizing as a process of informed reflection that integrates transformation and the development and application of new theory. By adding a practice-based perspective on knowledge (Blackler, 1995), we intend to transcend the cognitive perspective for which Kolb has been criticized (Illeris, 2000), his alleged lack of emphasis on reflection (Jarvis, 1992), and the tendency to overlook the importance of social dimensions, emotions, and power in organizations (Vince, 1998). We also hope to expand the level of analysis to include individuals and their learning, and collective and organizational transformation processes. Seeing these levels as interrelated is 
important in capacity building where developing, sharing, and applying knowledge in school organizations become pivotal (Harris, 2011).

We structure the article as follows: We start by revisiting John Dewey's and David Kolb's conceptualization of experience and knowledge development in relation to capacity building in schools. Then, we present our two cases and the studies we draw on. We next develop a theoretical framework in which we introduce a nondichotomous model, theorizing, and capacity building between the tyranny of theory and the tyranny of experience. Last, before the conclusion, we discuss the building of organizational knowledge in schools and emphasize cogenerative learning, the turn from individual to organizational knowledge, and the need for a pragmatic understanding of knowledge in organizations.

\section{The transformation of experience into new knowledge}

Developing knowledge in schools is essential in capacity building (Fullan, 2010; Harris, 2011; Sharrat \& Fullan, 2009). However, in the introduction to the Handbook of Organizational Learning and Knowledge Management where the two editors summarize the main challenges identified in the 28 chapters, they claim that we lack research on actual learning processes and knowledge. There is still a need for a better understanding of the relation between organizational learning and knowledge, and how knowledge is produced when the intention is to develop organizations, according to the two editors (Easterby-Smith \& Lyles, 2011).

Kolb (1984) depicted the process of developing knowledge with an experiential learning model and four sub-processes: Experience (1) is through reflection (2) transformed into concepts (3), and the concepts provide guidelines for active experimentation and testing of new experiences (4). Forming concepts (3) is more than formulating words; it is a process of theorizing where theories or models are developed to conceptualize the experience and are used for the experimentation with and testing of new experiences. New knowledge may then be developed to help us deal with novel situations we face or imagine. When we encounter a situation in which for some reason knowledge does not help, or where we are puzzled, or we discover a dissonance between what we know and what we realize we should know, a situation has arisen that calls for exploration. The exploration may be the start of a new transformation process, where we develop new theories to test.

When Kolb (1984) defined learning as "the process whereby knowledge is created through the transformation of experience" (p. 26), he built on Dewey's work. This definition places experience in relation to knowledge, where learning is the transformation process that reshapes experience into knowledge. According to Dewey (1929, pp. 242-243), knowledge is "the fruit of the undertakings that transform a problematic situation into a resolved one." Knowledge may be the answer to a question, a difficulty resolved, a confusion clarified, an inconsistency reduced to coherence, a perplexity mastered (Dewey, 1929, pp. 236-237). In this pragmatic tradition, knowledge makes it possible to understand, explain, deal with, and act in a more satisfactory way than previously, without meaning that assurance has replaced uncertainty: "The commonest fallacy is to suppose that since the state of doubt is 
accompanied by a feeling of uncertainty, knowledge arises when this feeling gives way to one of assurance" (Dewey, 1929, p. 237). If so, according to Dewey, the risk is that decisions will be made too quickly, and one will leap to conclusions and tend to simplify and confuse what is known with what is true. In other words, the knowledge we produce may reduce, but never remove, uncertainty.

Kolb's theory of experiential learning that places knowledge, learning, and experience in a mutual relationship is widely accepted (Illeris, 2000; Jarvis, 1992). Dewey's theory has also inspired scholars to develop similar models (see, e.g., Dixon, 1994; Revans, 1971, 1982, 1998; Wells, 2001). These models depict learning processes with different sequences or stages, such as experience, information, understanding, planning, reflection, observation, conceptualization, understanding, action, and experimenting. However, the Kolb tradition also has several shortcomings. Kolb's model may be read as a sequential process, starting with a person having an experience and then learning from it, which then results in knowledge. If the model is understood this way, it will imply a severe simplification, at least seen through the lenses of hermeneutic philosophy, which has long pointed out that any and all situations are understood and interpreted according to the knowledge an individual already possesses. We never make experiences without preconditions. No experience is gained without previous knowledge (Gadamer, 1960/2010). A separation of the individual and the social so that "...learning as a whole also becomes a completely internal phenomenon," as Illeris (2007, p. 55) claims that Kolb does, may also be problematic in light of Dewey, who described experience as a process with both individual and social sides. This point of view was later supported by neurobiological research (Damasio, 1994; LeDoux, 1996) and social learning theory (Vygotsky, 1978; Wenger, 1998): Experience, learning, knowledge, and the social are intertwined and very difficult to untangle. Thus, we cannot operate with absolute boundaries between experience, learning, and knowledge, or between the individual and the social. However, this is not the only way to read the model. It could also be understood as a tool for focusing attention on processes that are more entangled than a narrow reading of Kolb implies.

Kolb pointed to the importance of developing new theories in transforming experience into new knowledge. However, at least in his early works, Kolb primarily discussed the transformation into individual knowledge and showed less interest in organizational learning and knowledge. If knowledge remains only the teacher's, then that the transformation process has led to individual, not organizational, knowledge even if the transformation has taken place in a social context, for example, during a course or a conference or in a meeting with parents. In that case, educational change programs will not build systematic and collective capacity.

Capacity building is described by Fullan as the development of competencies, resources, and motivation. Individuals and groups are high in capacity "if they possess and continue to develop the knowledge and skills" and if they are "committed to putting the energy to get important things done collectively and continuously" (Fullan, 2010, p. 57). In the following, we introduce two cases that illustrate some of the challenges in developing and sustaining capacity. Then, we present a theoretical model that we use in a discussion of the role of theory and theorizing in collective capacity building. 


\section{Two cases}

Competence development has been a central strategy in Norway for building capacity in schools. The intention has been to increase teachers' professionalism and to develop schools into learning organizations in order to improve students' learning (Dehlin \& Author2, 2018). National programs such as New Effort and Lower Secondary in Development ${ }^{1}$ are relevant examples, as they were aimed at developing not only individual teachers' knowledge but also whole schools' shared knowledge through competence development programs.

\section{Case 1: New effort}

New Effort was launched in the autumn of 2010 by the Norwegian government as a system-wide 3-year program with the aim of getting more young people to complete upper secondary education and training. The program was operationalized through three sub-projects. Sub-project 3 (the Transition project) offered students in Year 10 who performed the most poorly (i.e., the $10 \%$ with the lowest grades) intensive teaching in reading, writing, and mathematics. Students were also offered summer courses in the holidays between Year 10 and the first year of upper secondary school.

To ensure the best possible quality in teaching, all schools that participated in the New Effort program were given the opportunity to send two teachers each to conferences and seminars. The idea was that these teachers would share their new knowledge with their colleagues when they returned from the conferences. The majority of the teachers had been selected because the school administration believed they were particularly suitable, many had a strong personal motivation for teaching academically weak students, and most specialized in the subject and had high competence (Sletten et al., 2011, p. 9). Thus, we may assume that the majority of the participating teachers were motivated and qualified.

New Effort typically invited two teachers from each school to be "served research in a seminar quite remote from their own classrooms" (Carlsten \& Markussen, 2014, p. 103). In the second program, Lower Secondary in Development, the strategy was altered: Teacher educators from the universities instead went to each school, where they conducted lectures and seminars for the whole staff and served as counselors.

\section{Case 2: Lower secondary in development}

"School-based Competence Development" was the main strategy to build capacity in the government-initiated national program Lower Secondary in Development (Ministry of Education and Research, 2012a). The program involved more than 1200 lower secondary schools.

\footnotetext{
${ }^{1}$ New Effort and Lower Secondary in Development are the authors' translation of Ny Giv and Ungdomstrinn i utvikling.
} 
Students' motivation to learn was at its lowest at the lower secondary level; this concerned the government. The proposed solution to the problem was to develop more varied ways of working in numeracy, reading, and writing, defined as basic skills, and to improve classroom management. The overall goal was more varied, more practical, and more motivating teaching in schools that learn as a whole, and not only as individual teachers. The need for collective capacity building was emphasized: The knowledge development process would, as opposed to the New Effort program, be school-based, and participation was mandatory. All teachers and leaders in every school should participate in in-school programs facilitated in collaboration with teacher educators from universities, and the national authorities would prepare support and guidance material. In this way, teachers would become familiar with updated research on numeracy, reading, writing, and classroom management to improve their teaching.

In a policy document, the Directorate for Education and Training (2013) defined school-based development of competence:

School-based development of competence means that the school, including its leaders and all staff, will take part in a development process at the workplace. The purpose is to develop the total amount of knowledge, attitudes and skills when it comes to learning, teaching and cooperation.

Teacher educators from universities were to assist the schools in capacity building. These experts were expected to share knowledge and offer advice on basic skills in each school, with assessment for learning and organizational learning as the overriding themes. The Directorate stated that the intention was to develop school as an organization and to achieve a lasting effect. Accordingly, capacity building must be systematic, occur over time, and include the organizational and individual levels, as well as the local, county, and national levels. Another aim was to build teacher educators' capacity through the experience they gained working closely with schools. Everyone involved was supposed to learn, according to the Directorate, from the Directorate to every teacher, and in the end, every student. However, as in the New Effort program, the evaluations of the Lower Secondary in Development program raised serious concerns.

\section{Learning from the two cases}

Both programs have been closely followed by researchers, and numerous reports have been published on New Effort as well as well as Lower Secondary in Development. We searched several of these reports, using search words such as "knowledge," "competence development," “capacity," "implementation," "lasting," "change," "diffusion," "improvement," “collective," "results," "students," "learning" and "organizational." We did so in order to narrow down our scope to challenges of producing organizational knowledge as a result of competence development measures. We were particularly interested in how participation in courses and seminars may or may not lead not only to professional development at the individual level, but also build collective capacity. We ended up with six reports 
(Markussen et al., 2015; Ministry of Education and Research, 2012b; Ministry of Education and Research, 2017; Postholm et al., 2013, 2018; Sletten et al., 2011). In the following, we will draw on some illustrative examples from these reports to discuss challenges of developing collective capacity in such a way that learning leads to organizational, and not only individual, knowledge.

In the New Effort program, the conferences and seminars were well received by the teachers who were selected to participate on behalf of their school, according to one of the studies: "The main impression from the survey is that these courses were very successful. Almost all the teachers believed that they would be able to use-at least some-of what they learnt from the course in New Effort teaching" (Sletten et al., 2011, p. 10). However, the researchers admitted that it was difficult to draw clear conclusions about whether this intensive teaching led to improved results for academically weak students (p. 8). In a report, the Ministry of Education and Research (2012b) pointed to the major differences between schools' systematic diffusion of the new knowledge and how it was taken into use (p. 16). In other words, some schools could not give an account of how the transformation process from individual teachers' learning to school development was supposed to occur. They had no plan or action theory that indicated how collective capacity building was supposed to happen, and it was hard to identify a systematic and coordinated effort aimed at transforming the participation in the program into new collective knowledge and improved teaching.

The New Effort program coordinators at the Ministry of Education and Research pointed to numerous challenges in building system capacity, one being dissemination of knowledge: The ministry worried how the knowledge gained by the selected teachers was disseminated in-house at the school, as well as in each municipality and county, so that over time the knowledge would provide qualitatively better teaching for all students after the New Effort program had ended. In the report, the ministry suggested that there were major differences between schools: "In some schools the competence teachers have acquired at the conferences and seminars is used deliberately and strategically to increase the competence of the whole staff, while teachers at other schools do not know why they were sent to the course or what happens afterward" (Ministry of Education and Research, 2012b, p. 16). However, the ministry's goal for the teachers who participated in these conferences and seminars was that teachers attended on behalf of the school, not primarily on their own behalf and that the teachers' professional development should lead not only to individual capacity building but also to building capacity in the whole school. How the teachers' experiences from participating in conferences and seminars should be transformed into organizational knowledge was found to be lacking.

A study of the pilot year in the Lower Secondary in Development program also found major differences among schools, as well as among principals. The group of researchers, including one of the authors of this article, conducted an evaluation that included a survey of 275 teachers in 20 schools, as well as focus group interviews with 54 teachers and principals at 9 schools (Postholm et al., 2013). The researchers found that in several schools there was little to suggest that the conferences and seminars that had been conducted for the staff would 
lead to lasting changes in the way teachers taught or in the schools' practices. The study of the pilot showed the following:

1. As in the New Effort case, an idea, program, or plan for how the teachers' experiences of participating in the program should be transformed into improved teaching and organizational knowledge, was often found lacking.

2. Accordingly, in many schools, reflection (and the testing of new teaching methods) was left up to the individual teacher. Few schools had organized collective reflection and collaboration in which teacher teams discussed and planned how new theory about numeracy, reading, writing, and classroom management could be applied.

3. Theory in the form of research-based articles was seldom used in collective reflection. Accordingly, in some schools the knowledge development process was not informed by research findings except models that the teacher educators shared when they provided lectures.

4. The role of the principals varied significantly, from very passive to very active in the school's capacity building.

Consequently, in several schools there was no deliberate effort to build the teachers' collective responsibility for students' learning and for development of the school as a learning organization. The responsibility was left up to the individual teacher. However, teachers' collective responsibility is a hallmark of the reflective, collaborative teams known as professional learning communities (Bolam et al., 2005), predictive of student learning (Goddard et al., 2000; Lee \& Smith, 1996), and pivotal for systemic capacity building (Sharrat \& Fullan, 2009).

In some schools, there was a greater degree of learning among teachers. They worked systematically and purposefully and tried new forms and methods (including observation of and reflection on teaching). In addition, teachers and leaders met and reflected on experiences and possible consequences. Time was allocated for collaboration, and the teachers read papers before they met so that they had common terminology and research-based knowledge for discussing their experiences. These practices were included in the indicator that the researchers called "school organizational learning," which was according to the teachers, the only significant explanation for successful school development (Postholm et al., 2013). The study concluded that it was not the conferences and seminars that were most important for school development to take place but how the schools worked after the courses, seminars, and other competence measures. Competence development in the form of seminars and other measures alone, although conducted collectively in the sense that all teachers and leaders participated, was insufficient for achieving sustainable changes in teaching that may improve student learning (Postholm et al., 2013).

The study was conducted during the early phase of the school-based competence program. However, an evaluation published 2 years later showed that only one out of five teachers in schools that participated in the program knew that they 
were participating, and only one out of five knew which basic skills the school had decided to concentrate on and which all teachers were supposed to improve. Not surprisingly, the researchers questioned the lasting effect in the schools and stated that the lack of anchoring and involvement ought to raise serious concerns (Markussen et al., 2015). A third study conducted during the last year of the program also pointed to the lack of teacher involvement and identified the initial phase in local schools and the involvement of teachers as decisive for successful school development efforts (Postholm et al., 2018).

The two cases we now have drawn on, seem both to exemplify the challenge of developing collective capacity in such a way that learning leads to organizational, not only individual, knowledge. Even in the school-based Lower Secondary in Development program, in which all teachers and leaders were supposed to participate and learn as a collective, there was a lack of involvement and genuine anchoring, and the lasting effect on the school was questioned. Lower Secondary in Development and New Effort programs are, however, just two out of a series of nation-wide programs the last decade. It is therefore relevant to ask how representative they are. According to the Ministry, they do not stand from the rest. In a report to the parliament, the Ministry summarized several studies of a larger number of the nation-wide programs, and concluded that the programs had not sufficiently met local needs and had not considered the complexity of implementation, and were characterized by a lack of anchoring and involvement (Ministry of Education and Research, 2017).

The Ministry's conclusion led to a new, decentralized competence model that provided schools and municipalities more freedom to carry out systematic school improvements locally. The new model resembled several of the ideas behind the Lower Secondary in Development program: A whole school approach and cooperation in partnerships with municipalities, universities and university colleges, and other competence partners. In 2019, the OECD published a report on this new decentralized competence development model (OECD, 2019). The OECD had engaged with Norway to support the implementation of the model, as part of its work centered on education policy implementation. The report presents “...OECD's assessment and proposes suggestions for the implementation strategy of the new competence development model." While the report underscores the need for cooperation, and makes use of an article by one of the authors (Author2, 2018), it does to a little degree discuss central topics in the article such as how democratic cogenerative knowledge creation in education change may be improved. The focus is on the need for "...clear, high-priority, measurable, ambitious but feasible goals" (p.26), assessment and evaluation, implementation, and incentives. ${ }^{2}$ This gives the impression of a structural perspective on implementation of education policies, rather than a report on how to create knowledge in local schools, and what form this knowledge may take in the school as an organization. It also strengthens our initial claim; that it

\footnotetext{
2 Assessment/assess/assessing is mentioned 87 times in this 100 pages document, evaluation/evaluating 111 times, implementation/implementing 279 times, accountability/accountable 43 times and incentives 27 times.
} 
seems to be a need for theoretical perspectives that may help conceptualize and aid knowledge development in capacity building.

\section{Theoretical framework}

The two cases we have used as illustrations, built on different strategies but had in common that both aimed at bringing in theory from research to inform professional and school development. The relationship between theory and practice in education has typically been understood as a dichotomy (Carr, 1995; Weniger, 1953). When competence development is a strategy for improving teaching in schools and for building collective capacity, this strategy may then be understood dichotomically as a transfer and implementation problem: New knowledge, typically generated from research, exists. The challenge is how to communicate this evidence-based knowledge in the "gap" between theory and practice so that teachers and school leaders disseminate and implement "what works" with fidelity (Shirley, 2016). Knowledge may then be seen as a static entity (Blackler, 1995), and educational change may tend to be understood as implementation, in a tradition where implementation is seen as "a specified set of activities designed to put into practice an activity or program of known dimensions" (Fixsen, 2005, p. 5). However, capacity building requires creating knowledge (Harris, 2011; Sharrat \& Fullan, 2009), which is different from putting into practice something that is already known by faithfully following a pre-programmed activity.

We acknowledge that a dichotomous view, with theory on one side and practice on the other, has its strengths, but we also worry that it may hamper knowledge development (Ertsås \& Irgens, 2016). In the following, we emphasize theorizing rather than theory, where theory and practice are entangled in process rather than separated in static categories (Ertsås \& Irgens, 2016; Hernes, 2008; Weick, 1989, 1993). This does not mean that we downplay the role of theory, but we see theory as a dimension instead of a category (Weick, 1989). Such an understanding of theory, which implies a differentiation of the theory concept and a non-dichotomous perception of the relationship between theory and practice, is vital in Weniger's theory concept and the hermeneutical understanding of theory in the humanities (Ertsås, 2011).

\section{Theorizing in capacity building}

Erich Weniger (1953), a representative of the European continental hermeneutic tradition, was an early advocate of a graded theory concept. In the 1920s, he depicted the relationship between theory and practice as differing degrees of theory: Theory of the third degree, which we call T3, is what people usually associate with theory, something abstract that theoreticians and researchers produce, and is typically found aggregated at a generic level in textbooks and articles. However, all people have theories, according to Weniger, and people develop theories as a way of producing new knowledge for use in practice. Theory of the second degree, which we call 


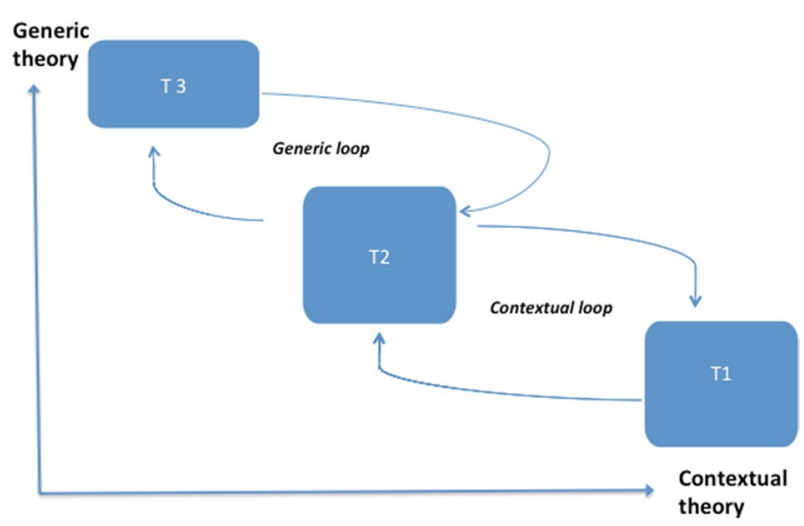

Fig. 1 Theorizing in capacity building. The T model. This is a processed version of a model we used in Ertsås (2011), and Ertsås and Irgens (2012, 2016).

T2, are the beliefs a person holds and that he or she may formulate in one way or another, for example as descriptions of what they are doing. Last, we have theory that according to Weniger is hidden in what people actually do, theory of the first degree, which we refer to as $\mathrm{T} 1$.

Theory of the third degree, T3, is typically the results of the theorizing that are carried out by theoreticians "in silence and on paper," as Ryle (1949, p. 16) put it. These theories are normally publicized, formulated, and presented more explicitly than the $\mathrm{T} 1$ theories that are embedded in practice. T3 is typically less context-specific and more generic (Weick, 1989) and can be found in research papers, books, and articles, as well as in regulatory documents, such as education acts, curricula, regulations, and lectures and presentations of successful educational change processes (Ertsås \& Irgens, 2016).

In this graded model, theory and practice should be understood as entangled in process rather than as disconnected and static categories. This is a process view in which there is no clear distinction between where theory ends and practice begins. We have tried to illustrate the process in the T model in Fig. 1. In the model, T3, $\mathrm{T} 2$, and $\mathrm{T} 1$ are dimensions on a continuum rather than categories and represent processes rather than static states (Weick, 1989). In this non-dichotomous model, also practice is loaded with theory and may be improved by developing new and better theories for use through processes of theorizing and experimenting in specific contexts.

T1 and T2 are parallel to what Argyris and Schön (1978) named action theories, where $\mathrm{T} 1$ is the practitioner's theory-in-use, a theory in practice that cannot be identified based on what is said; the theory must be identified through observation of what is actually done. This indicates that $\mathrm{T} 1$ is characterized by a dimension of tacitness (Damasio, 1999; Dreyfus \& Dreyfus, 2005; Schön, 1983), which, however, does not imply that the action theories in $\mathrm{T} 1$ are completely inaccessible to the practitioner. There are degrees of tacitness (Polanyi, 1966, 1969), and describing theory that acts as the background for what is actually done may take deliberation and effort. Formal and informal feedback from parents, students, colleagues, and leaders, 
as well as test scores and data from assessments and surveys, combined with mindful and ongoing reflection on a teacher's professional performance and discussions in teacher groups, may help a teacher gain better insight into the theories in use in her or his teaching method.

A practitioner may try to express his or her action theories in $\mathrm{T} 2$, for example, in the form of theses, in experiential statements or in theorems, that is, as a theory the practitioner can articulate. The theories articulated in T2 may also serve as the practitioner's rationale for his actions and express the understanding he has of himself and his professional practice. Then, T2 is close to what Argyris and Schön (1978) called espoused theories.

To sum up with an illustration, a teacher may find inspiration and advice when attending a conference where she encounters new research, indicated by $\mathrm{T} 3$ in Fig. 1. Reflecting (T2) on her own theories-in-use (T1) in light of what she has now read or heard (T3), she thinks through and develops ideas and action steps for how she can improve her own teaching. By trying out her ideas in practice, and reflecting on what she then experiences, she may improve the theories (T1) embedded in her teaching and become more conscious of the theories she applies in her work.

This example shows teacher knowledge development as a process of informed reflection that we define as professional theorizing: a process in which an individual or a group reflects on, formulates, analyzes, gives rationales for, and develops practice with theory of varying degrees. However, as the two cases illustrate, individual learning processes are not sufficient when the ambition is to develop organizational, and not only individual, knowledge. This ambition also requires transformation through collective reflection, evaluation, and planning, that is, through collective theorizing in T2. Kolb's (1984) depiction of experiential learning theory and Blackler's (1995) distinction between static and practice-based knowledge may be useful, but inadequate, tools for understanding the challenges of developing collective capacity and organizational knowledge. We also need to conceptualize the role of theorizing in collective capacity building.

\section{Capacity building between the tyranny of theory and the tyranny of experience}

Theorizing is something all people do, according to Gilbert Ryle (1949, p. 16), but they usually carry it out in silence, and seldom on paper, as is customary among theoreticians. Theorizing may be done intelligently and stupidly, as Ryle (1949, p. 26) pointed out. However, we have certain expectations for how professionals should theorize (Eraut, 1994; Weniger, 1953). For example, we feel more confident if we know that a physician has access to relevant and updated research knowledge (T3) when about to diagnose and recommend surgery, and we feel safer if we know that the surgeon is skillful and has first-hand experience from carrying out the operation (T1). In addition, we appreciate that the professional is capable of explaining why the surgery is recommended and how it is to be carried out (T2). This way of explaining and legitimizing conduct may then lead to attributions of professional authority. 
If a teacher's theorizing is informed only by $\mathrm{T} 1$, it means that his or her professional development is closed in the sense that it is restricted to the contextual, inward-focused learning loop in Fig. 1 and to what is learned in and from the local context. This also counts for a school's teacher collective, and may lead to a culture characterized by what Weniger (1953) called "tyranny of experience," an uncritical belief in the value of one's own experiences that is used to legitimize the continuation of old practices. Brookfield (1995) described the tyranny of experience as conduct built on common-sense assumptions, where teachers base their knowledge development on primary experiences and by copying colleagues.

Collective theorizing in T2 may result in espoused theories in the form of plans, charts, rules, procedures, standards value documents, and programs, as well as less formalized ways to describe "how we do things here." Change in T2 does not necessarily mean that practice (e.g., teaching methods) is improved or that new rules, standards for professional conduct, or a program for reducing bullying is carried out. That would require a change in T1, in the school's theories-in-use.

Local knowledge is contextual knowledge, according to Yanow (2004), but if an entire school's knowledge development is characterized by closed and inward learning loops, the development will become increasingly myopic. It will be not only context dependent but also context restricted. Alternative perspectives will often be ignored, and new knowledge from outside will only rarely confront the school's established practices and theories-in-use. The culture may become "set" (Swidler, 1986), and the dominant local ideology may be taken as given (Czarniawska, 1997). Without T3 in the form of research-informed and less context-restricted knowledge for use in a meta-theoretical perspective, it gradually becomes natural to do school the way one is used to, without being challenged by new ideas from "out there" (Wilden, 1987).

Inward-looking and context-restricted knowledge development may be avoided if T3 informs school development and teachers' professional development. Through the generic learning loop, T3 may be brought in to monitor and contribute to "correcting myopia." But if the value of practical experiences is devaluated, research and steering documents are attributed a canonical status, "best practice" and "what works" are celebrated, and T3 is allowed to dominate, we risk ending up with "a tyranny of theory" (Weniger, 1953). Even the most impressive generic theory-perhaps in particular the most impressive ones-must be tested in use if its pragmatic validity is to be confirmed (Worren et al., 2002). However, if teachers become subservient to and credulous about the theory of the third degree, this belief may lead to unreflected attempts to implement generic recipes in specific contexts and what Donald Schön (1983) called unique zones of practice. If teachers resist, they may be blamed for not implementing "what works" and for building their teaching on experience and ideology rather than evidence. If the pressure to conform to given standards is strong and lasting, it may also lead to hypocrisy, according to Brunsson (1995). What is expressed in T2 is then different from what is carried out in T1, and hypocrisy becomes a strategy for maintaining business as usual. In the worst scenarios, organizations deserve a psychiatric diagnosis (Kets de Vries \& Miller, 1984): neurotic schools where employees dare not take responsibility for fear of being 
penalized for mistakes, schizophrenic schools that have multiple identities, and paranoid schools where one feels persecuted by all and sundry.

To avoid the tyranny of theory and the tyranny of experience, professional and school development should be informed by T1 and by T3 in T2, that is, in a theorizing process of informed reflection that integrates transformation of existing theory and the development and application of new theory to be tested in T1. The following questions could help during the theorizing process: How should we work in our school or team to improve the quality of our teaching? Which research findings could then guide us? What have we learned from previous and present experience that we can draw on? What can we do differently and better, and how can we model and test new ways of teaching? What could hinder us from doing this, and how should we handle such hindrances? How can we increase the likelihood that what we learn becomes not only individual but also organizational knowledge?

Although these questions may seem trivial, the two cases showed that this is not necessarily so. A model such as the T model, supported by organizational learning theories such as Argyris \& Schön's single and double loop learning (1978) and March' theory on exploration and exploitation in organizational learning (1991), may hopefully be of help in understanding and coping with the type of challenges these questions address.

\section{Building organizational knowledge in schools}

The overriding idea in both of the cases, was collective capacity building. Every school should learn as an organization, with competence programs in which professional competence is developed and practice improved, individually and collectively. In both cases, the competence development measures, such as numeracy, reading, writing, and classroom management, were conducted or assisted by teacher educators assumed to be among the best in their fields. Thus, we can assume that the schools got access to the most updated T3 that was available. However, the transformation of research-based theory (T3) to improved practice as a change in theoriesin-use (T1) proved to be problematic in many schools. There were significant differences between the schools in how systematically they worked to improve their T1, that is, how they changed their theories-in-use, and how they designed and described the transformation process as an espoused theory in $\mathrm{T} 2$.

The competence measures conducted by the university experts were insufficient for the goal of improving the schools. The key to success was how the schools worked after, when, so to speak, they were left on their own (Postholm et al., 2013, 2018). How teachers and leaders developed their theories for improving practice seemed to be pivotal for capacity building in both cases, as well as for their collective teacher efficacy belief. "When a school staff shares the belief that through their collective actions they can positively influence student outcomes, student achievement increases," as Donahoo puts it (2017, p. XV). According to the teachers themselves in the Lower Secondary in Development program, the probability was highest for improvement in students' learning when there was systematic learning among teachers, collective planning, evaluation of their own practice, and observation of 
and reflection on teaching (Postholm et al., 2013, p. 123). Capacity building seemed to happen as cogenerative learning characterized by mobilization and the development of local theory (Elden \& Levin, 1990).

\section{Capacity building as cogenerative learning}

Seen through the lens of the T model in Fig. 1, the importance of T2 as a collective reflection on the usefulness of T3 in light of local challenges, becomes evident. In some schools in the Lower Secondary in Development program, there was collective reflection on the usefulness of $\mathrm{T} 3$, how $\mathrm{T} 3$ challenged existing practices in $\mathrm{T} 1$, and how $\mathrm{T} 3$ in connection with the school's best practices in T1 could be transformed into better teaching or classroom management (Postholm, 2018). Through these informed discussions, individual teachers and teams developed T2 in the form of improved espoused theories (Argyris \& Schön, 1978). These action theories were not used as fixed recipes for an implementation process of new T3 in T1 but as preliminary ideas, guidelines, sketches, or designs that expressed the teachers' and the teams' ongoing theorizing about how to improve practice and what to learn from it.

In the $\mathrm{T}$ model, $\mathrm{T} 2$ is key to succeed in improving classroom practice. However, the transformation process that may end in new knowledge is necessarily different when organizational and not individual knowledge is the goal. Individual theorizing does not require collaboration, but collective reflection in teacher teams demands structured time (Datnow \& Hubbard, 2016). Schools that seemed to succeed more than others had, according to the teachers, organized time for teams (Postholm et al., 2013). In the teams, the teachers discussed what the new T3 knowledge might imply for their teaching, how they could try out new forms of teaching and collaboration, and how they, as colleagues, could observe and further develop their T1, that is, how they succeeded or not in their attempt to improve practice. The teachers also reported the latter back in team meetings and read articles and white papers as preparation for these discussions (Postholm et al., 2018). This is a way of developing a more conscious T2, whereby the teachers may gradually become more knowledgeable about how to go about to improve teaching and collaboration methods. The teachers did not implement static knowledge (Blackler, 1995) from T3 but transformed what they found most useful through collective reflection. This seemed to lead to a more conscious understanding of what it took to improve their own teaching and how they ought to collaborate as professional teachers. In other words, the teachers built capacity collectively through theorizing, and they did so informed by $\mathrm{T} 3$ and $\mathrm{T} 1$.

Instead of following an "order and delivery" model influenced by economic theory, such as agency theory (Jensen \& Meckling, 1976), in which competence development tends to become "content delivery," implementation, application, or translation of a given T3 (Irgens \& Ertsås, 2008; Irgens, 2018; Nygaard \& Bramming, 2008; Nygaard \& Holtham, 2008; Snow, 2014), some schools established partnerships (Snow, 2014) and cooperated with the university experts in a tradition that resembled cogenerative learning (Elden \& Levin, 1990). Instead of attempting to implement T3 through predetermined procedures (Fixsen et al., 2005), the schools 
focused on communication, local mobilization, and the development of local theory (Elden, 1983). The process seemed to have much in common with what Greenwood and Levin (1998) labeled action research: "Together, the professional researcher and the stakeholders define the problems to be examined, cogenerate relevant knowledge about them, learn and execute social research techniques, take actions, and interpret the results of actions based on what they have learned" (p. 4).

Transforming T3 into shared and, at least to some degree, lasting organizational knowledge seems to have been challenging in the two cases. Not only is it important to reflect collectively and work systematically to improve the current practice, but also to find ways to build the school's capacity so that important knowledge that was cogenerated becomes organizational and makes a lasting impact (Dehlin \& Irgens, 2018). If knowledge is the fruit of learning (Dewey, 1929), one should also consider how this fruit ought to be saved in schools and the role of knowledge in organizations.

\section{From individual to organizational knowledge}

How actors understand knowledge is an ontological assumption that, if taken for granted, may be decisive for how they plan, talk about, and implement changes and how a model such as the T model in Fig. 1 is applied. How to understand knowledge in organizations is a problem that has been treated by a series of authors (see, e.g., Brown \& Duguid, 2001; Cook \& Brown, 1999; Gherardi, 2009). Some have discussed how different ontological and epistemological assumptions seem to lead to two different understandings, one tradition that sees knowledge as static, as "truth" and as a "thing," and one as processual, "practice," "process," and "relations" (Hamlin et al., 2001; Newell et al., 2002).

Blackler (1995) argued that the static perspective is the most widely used method of understanding knowledge in organizations. It is seen as static and structural, where knowledge is understood as a noun, something found somewhere in the organization that can be retrieved when the situation calls for it. Knowledge then may be seen as embrained, embodied, encultured, embedded, and encoded.

If teachers, university experts, or school leaders favor embrained knowledge, it is likely that courses in, for instance, core subjects will be the preferred strategy, possibly with emphasis on developing a common concept apparatus and common knowledge about models and teaching strategies. This was dominant in the first phase of the Lower Secondary in Development program, in which an "order and deliver rhetoric" where competence development was seen as a transaction became distinct among principals and university experts. The latter were expected to deliver the lectures and other competence measures that the principals called for (Postholm et al., 2013). When it became evident that this model had little effect on local capacity building, the Directorate of Education underscored that university experts primarily should take on roles of competence partners and facilitators rather than give lectures (Dehlin \& Author2, 2018, p. 245). The change gave way to a stronger focus on embodied knowledge and methods teachers could test in practice to develop better practical skills in the classroom. In some schools, encultured knowledge also 
became a topic, as shared values, norms, pedagogical principles, and other aspects of the school culture were discussed. Some schools also tried to embed knowledge, as they attempted to apply new routines and practices. Some likewise tried to encode knowledge in learning platform systems, timetables, and other systems that supported collaboration and information sharing.

These situations are, according to Blackler (1995), examples of a static view of knowledge. In both cases, a static perspective seemed to dominate the practice perspective. In the practice perspective, knowledge is a dynamic and processual phenomenon: Knowledge then can be understood as mediated, situated, provisional, pragmatic, and contested, following Blackler. That knowledge is mediated means that it does not come to us in an unfiltered form, and the knowledge does not randomly take its form. The knowledge is influenced by the media the knowledge traverses and is formed by, and this media may range from language to technology to forms of collaboration and forms of control. That knowledge is situated means that it is not generally valid but is connected to time and space and the context where the knowledge is used. That knowledge is provisional means that it is temporary; its validity lasts as long as the knowledge has relevance and a dominant position. One reason is that knowledge is pragmatic, that is, focused on understanding particular problem areas or resolving specific tasks, and contested, which means that knowledge represents power and dominance and that any form of knowledge will sooner or later be challenged by other views of knowledge.

If a static perspective dominates, the theorizing in $\mathrm{T} 2$ may become a process of instrumental rationalization (Townley et al., 2003), and the volatile nature of knowledge may be unheeded. But regardless of how effectively new knowledge is embrained, embodied, encultured, embedded, or encoded, it may, sooner or later, be challenged, ignored, forgotten, or even hated. Emotions drive many of the decisions we make (Damasio, 1994), and school organizations are no exception. If the knowledge on which we are expected to base our professional conduct does not help us in specific contexts, then the knowledge likely will trigger frustration or other emotional responses and shape our attitude toward the knowledge we are supposed to apply. If a static view of knowledge dominates, we may tend to ignore how these affective processes evolve. Our attention may be drawn to what the German philosopher Ernst Cassirer (1944) called the surface structure of reality. If this structural view continues to dominate, we may develop what Cassirer called habitual blindness. It will gradually reduce our ability to see "what is still not here" and "what is not on the surface." We may see some aspects clearly but typically, the ones that are most concrete and easy to identify. We risk losing sight of deep-level phenomena, such as values, norms, interpretations, feelings, and mental images (Irgens, 2011, p. 45), and how they influence organizational behavior (Irgens, 2011).

\section{A pragmatic understanding of knowledge in organizations}

Blackler's two perspectives, the static (in the literature also called structural, instrumental, positivist, functionalist, and objectivist) and the practice-oriented (also called processual, pragmatic, and constructivist), may be understood as alternatives: You 
subscribe to either a static perspective or a practice perspective. However, we adopt a pragmatic point of view (James, 1890) and maintain that the two perspectives can supplement each other and together help us understand why the development of organizational knowledge is difficult. Acknowledging that the very nature of knowledge is volatile, the static perspective can give us simplified but nevertheless useful presentations of how one should try to "ensure" and "take care of" knowledge in an organization. The practice-oriented perspective may, however, help us see that knowledge is a process and movement rather than a static entity, linked to power, emotions, and hegemony, and thus, will remain contested and temporary. This perspective may help us understand what happens to knowledge, and why, despite good intentions, achieving lasting improvements may be difficult. Together with the static perspective, the practice perspective may give us better answers to questions such as those we formulated in the introduction: What can impede the new knowledge from leading to widespread and lasting improvements in teaching and forms of collaboration? What can increase the probability that we achieve improvements all the way into the classroom? How can we increase the likelihood that the school as an organization, and not only individual teachers, learn?

More specifically, by seeing knowledge in school as mediated, one may theorize in an initial phase how T3 may become processed, filtered, and recreated in the transformation from T3 to the classroom (T1). Who has the power to influence the interpretation process? Which cultural filters must the knowledge pass through, and what happens to it then? Which defensive routines (Argyris \& Schön, 1978) will probably be put into play, and what effect might they have? By seeing knowledge as situated, one may focus on the dilemmas that may arise when T3 in the form of generic knowledge is juxtaposed with local context-dependent knowledge and different T1s. What characterizes the knowledge that already exists in different teams? A situated understanding of knowledge is, in turn, the gateway to understanding knowledge as pragmatic, provisional, and contested, where T3 is temporary and will not answer the school's challenges once and for all, dependent on the perceived pragmatic validity of the knowledge, and challenged by other views of what is the best and most useful knowledge. What needs for knowledge are not satisfied by the measures we are launching, and when and how should we initiate new competence measures? How long may we assume that the new T3s will be relevant for our school? What will happen when new ideas and prescriptions and imperatives (Shirley, 2016) arrive to replace what we have learned? Which views of knowledge and practice in our school will be challenged by new T3, and how might this play out in T1? How will new T3 be questioned on the way from a course or other measures to the classroom? Which negotiation processes (Wenger, 1998) must we be prepared to participate in, and how can we organize collective reflection in $\mathrm{T} 2$ informed by $\mathrm{T} 1$ and $\mathrm{T} 3$ ? These are examples of questions that may help us bring a practice perspective into theorizing. 


\section{Conclusion}

In this article, we have drawn on two nation-wide educational change programs as exemplary cases to discuss the role of theory and theorizing in developing the collective capacity of schools, understood as a knowledge-building process (Sharrat \& Fullan, 2009, p. 8). In the New Effort and Lower Secondary in Development programs, conferences, courses, and seminars had specified knowledge themes, such as numeracy, reading, writing, and classroom management. In this article, we have tried to show how generic theory contributed by such competence measures must undergo transformation processes so it can be assessed, contextualized, and tested in local practice, a process through which new relevant, local knowledge may be generated. For these transformations to occur with as much awareness as possible and lead to organizational and not only individual knowledge, this also means that schools may not only need theory in classroom management and in subjects such as reading, writing, and mathematics (the content elements of the courses and other competence measures). They may also need theory to help them develop their own theories through theorizing about how new generic, aggregated, and less context-specific theories (T3) may be transformed and local and context-specific knowledge cogenerated, and the challenges they may have to cope with when transforming the theories that are already embedded in their local practices (T1).

The article adds to the capacity building literature in several ways. We developed a theoretical perspective that can be applied by course providers, teachers, and school leaders when attempting to build sustaining capacity and serve as an analytical tool for those who study schools and educational change. We developed this perspective by supplementing Kolb's (1984) thinking on how knowledge is developed with a model that shows the importance of theorizing to improve practice. We also brought in organizational learning theory (Argyris \& Schön, 1978) and a pragmatic view, in which the practice perspective (Blackler, 1995) may help us understand the volatile nature of organizational knowledge.

However, the extent to which our contribution is relevant and useful as a tool for analyzing and improving practice in schools cannot be answered with generic theory alone. This article is an example of generic theory, and the article's usefulness as T3 must accordingly be tested and transformed in T2 as well as in T1.

Funding Open access funding provided by NTNU Norwegian University of Science and Technology (incl St. Olavs Hospital - Trondheim University Hospital).

Open Access This article is licensed under a Creative Commons Attribution 4.0 International License, which permits use, sharing, adaptation, distribution and reproduction in any medium or format, as long as you give appropriate credit to the original author(s) and the source, provide a link to the Creative Commons licence, and indicate if changes were made. The images or other third party material in this article are included in the article's Creative Commons licence, unless indicated otherwise in a credit line to the material. If material is not included in the article's Creative Commons licence and your intended use is not permitted by statutory regulation or exceeds the permitted use, you will need to obtain permission directly from the copyright holder. To view a copy of this licence, visit http://creativecommons.org/licen ses/by/4.0/. 


\section{References}

Argyris, C., \& Schön, D. (1978). Organizational learning: A theory of action perspective. Addison-Wesley.

Blackler, F. (1995). Knowledge, knowledge work and organizations: An overview and interpretation. Organization Studies, 16(6), 1021-1046.

Bolam, R., McMahon, A., Stoll, L., Thomas, S., \& Wallace, M. (2005). Creating and sustaining effective professional learning communities (Research report RR637). University of Bristol.

Brookfield, S. (1995). Becoming a critically reflective teacher. Jossey-Bass.

Brown, J. S., \& Duguid, P. (2001). Knowledge and organization: A social practice perspective. Organization Science, 12, 198-213.

Brunsson, N. (1995). Ideas and actions: Justification and hypocrisy as alternatives to control. Research in the Sociology of Organizations, 13, 211-235.

Bryk, A. S., Sebring, P. B., Allensworth, E., Luppescu, S., \& Easton, J. Q. (2010). Organizing schools for improvement: Lessons from Chicago. University of Chicago Press.

Carlsten, T. C., \& Markussen, E. (2014). Phased implementation: Successful alignment of tools of implementation to improve motivation and mastery in lower secondary schools in Norway. In F. Nyhamn \& T. Hopfenbeck (Eds.), From political decisions to change in the classroom: Successful implementation of education policy CIDREE yearbook 2014 (pp. 96-117). Udir.

Carr, W. (1995). For education. Towards critical educational enquiry. Open University Press.

Cassirer, E. (1944). An essay on man. Yale University Press.

Cook, S., \& Brown, J. (1999). Bridging epistemologies: The generative dance between organizational knowledge and organizational knowing. Organization Science, 10(4), 381-400.

Czarniawska, B. (1997). A narrative approach to organization studies. Sage.

Damasio, A. R. (1994). Descartes' error. Emotion, reason and the human brain. Avon Books.

Damasio, A. R. (1999). The Feeling of What Happens: Body and Emotion in the Making of Consciousness. New York: Harvest.

Datnow, A., \& Hubbard, L. (2016). Teacher capacity for and beliefs about data-driven decision-making: A literature review of international research. Journal of Educational Change, 17(1), 7-28.

Dehlin, E., Irgens, E. J. (2017). Kunnskap som struktur i mote med kunnskap som praksis: Dilemma og spenninger i norsk skoleutvikling. [Knowledge as structure versus knowledge as practice: Dilemmas and tensions in Norwegian school development.] In: Postholm, M. B. Kunnskap for en bedre skole. Etter- og videreutdanning som strategi. Bergen: Fagbokforlaget, pp. 161-188.

Dehlin, E. \& Irgens, E. J. (2018). Case C. In: Postholm, M.B.; Normann, A; Dahl, T.; Dehlin, E.; Engvik, G.; Irgens, E. J. (2018) (Eds.). Skole- og utdanningssektoren i utvikling. (pp. 225-271.) Bergen: Fagbokforlaget.

Dewey, J. (1929). The quest for certainty. A study of the relation of knowledge and action. Gifford lectures. New York: Milton Balch.

Directorate of Education and Training. (2013). Rammeverk for skolebasert kompetanseutvikling på ungdomstrinnet 2013-2017 [Framework for School-based Competence Development on the lower secondary level]. Oslo: The Norwegian Directorate for Education and Training. Retrieved April 25, 2014 from www.udir.no.

Dixon, N. (1994). The organizational learning cycle: How we can learn collectively. McGraw-Hill.

Donohoo, J. (2017). Collective efficacy: How educators' beliefs impact student learning. Corwin.

Dreyfus, H. L., \& Dreyfus, S. E. (2005). Expertise in real world contexts. Organization Studies, 26, 779-792.

Dodgson, M. (1993). Organizational learning: A review of some literatures. Organization Studies, 14(3), 375-394.

DuFour, R., \& Eaker, R. (1998). Professional learning communities at work: Best practices for enhancing student achievement. Solution Tree Press.

Elden, M. (1983). Democratization and participative research in developing local theory. Journal of Occupational Behavior, 4, 21-33.

Elden, M., \& Levin, M. (1990). Cogenerative learning: Bringing participation into action research. In W. F. Whyte (Ed.), Participatory action research (pp. 127-142). Sage.

Eraut, M. (1994). Developing professional knowledge and competence. The Falmer Press.

Ertsås, T. I. (2011). Kontaktlarerarbeid i videregående skole. En kvalitativ studie av kontaktlareres utvikling av praksiskunnskap [The work of homeroom teachers in upper secondary school. A 
qualitative study of home-room teacher development of practice knowledge] (Unpublished doctoral dissertation). NTNU, Trondheim, Norway.

Ertsås, T. I., \& Irgens, E. J. (2012). Teoriens betydning for profesjonell yrkesutøvelse [The importance of theory for professional performance of a vocation]. In M. B. Postholm (Eds.), Læreres læring og ledelse av profesjonsutvikling (pp. 196-215). Trondheim, Norway: Tapir Akademisk Forlag

Ertsås, T. I., \& Irgens, E. J. (2016). Professional theorizing. Teachers and Teaching, 23(3). https://doi.org/ 10.1080/13540602.2016.1205013.

Fixsen, D. L., Naoom, S. F., Blase, K. A., Friedman, R. M., \& Wallace, F. (2005). Implementation Research: A Synthesis of theLiterature. Tampa: Florida University.

Fullan, M. (2010). All systems go: The change imperative for whole system reform. Corwin Press.

Gadamer H-G (1960/2010). Sannhet og Metode [Truth and method]. Oslo, Norway: PAX

Gherardi, S. (2009). Introduction: The critical power of the practice lens. Management Learning, 40(2), $115-128$.

Goddard, R. D., Hoy, W. K., \& Woolfolk, A. (2000). Collective teacher efficacy: Its meaning, measure, and effect on student achievement. American Education Research Journal, 37(2), 479-507.

Greenwood, D. J., \& Levin, M. (1998). Introduction to Action Research: Social Research for Social Change. Sage Publications.

Hamlin, B., Keep, J., \& Ash, K. (2001). Organizational change and development: A reflective guide for managers, trainers and developers. Pearson Education.

Hargreaves, A., \& Fullan, M. (2012). Professional capital: Transforming teaching in every school. Teachers College Press.

Harris, A. (2011). System improvement through collective capacity building. Journal of Educational Administration, 49(6), 624-636.

Hernes, T. (2008). Understanding organization as process: Theory for a tangled world. Routledge.

Illeris, K. (2000). Tekster om laring [Texts on learning]. Roskilde Universitetsforlag.

Illeris, K. (2007). How We Learn: Learning and Non-Learning in School and Beyond. London: Routledge.

Irgens, E. J. (2011). Pluralism in Management: Organizational Theory, Management Education, and Ernst Cassirer. New York:Routledge.

Irgens, E. J. (2018). Historical amnesia. Nordic Journal of Comparative and International Education (NJCIE), Vol. 2/2-3, pp. 25-38. https://doi.org/10.7577/njcie.2806.

Irgens, E. J., \& Ertsås, T. I. (2008). Higher education as competence program providers in a nationwide school reform. In: C.Nygaard \& C. Holtham (Eds.), Understanding Learning-Centred Higher Education (pp. 265-282). Copenhagen: CBS Press.

James, W. (1890). The principles of psychology. Dover.

Jarvis, P. (1992). Paradoxes of learning: On becoming an individual in a society. Jossey-Bass.

Jensen, M., \& Meckling, W. (1976). The theory of the firm: Managerial behavior, agency costs, and ownership structure. Journal of Financial Economics, 3(4), 305-360.

de Vries, M. F. K., \& Miller, D. (1984). The neurotic organization. Jossey-Bass.

Kolb, D. A. (1976). Learning style inventory. McBer.

Kolb, D. A. (1984). Experiential learning: Experience as the source of learning and development. Prentice-Hall.

Kools, M., \& Stoll, L. (2016). What makes a school a learning organisation? (OECD Working paper, No. 137). Paris, France: OECD.

Kruse, S. D., Louis, K. S., \& Bryk, A. (1994). Professional community in schools. Issues in Restructuring Schools, 6, 3-6.

LeDoux, J. (1996). The emotional brain: The mysterious underpinnings of emotional life. Simon \& Schuster.

Lee, V. E., \& Smith, J. B. (1996). Collective responsibility for learning and its effects on gains in achievement for early secondary school students. American Journal of Education, 104, 103-147.

Leithwood, K., Jantzi, D., \& Steinbach, R. (1995). An organisational learning perspective on school responses to central policy initiatives. School Organisation, 15(3), 229-252.

March, J. G. (1991). Exploration and exploitation in organizational learning. Organization Science, 2(1), 71-87.

Markussen, E., Carlsten, T. C., Seland, I., \& Sjaastad, J. (2015). Fra politisk visjon til virkeligheten i klasserommet: Evaluering av virkemidlene i Ungdomstrinn i utvikling. Delrapport 2. NIFU- 2015:27 
[From political vision to reality in the classroom. Evaluation of the strategies applied in lower secondary in development. Report \#2]. Oslo, Norway: NIFU.

Markussen, E., Carlsten, T. C., Seland, I., \& Sjaastad, J. (2016). Evaluering av virkemidlene $i$ Ungdomstrinn $i$ utvikling. [Evaluation of the strategies applied in lower secondary in development]. NIFU.

Ministry of Education and Research (2004). St. Meld. nr. 30 (2003-2004). Kultur for laring [Culture for learning]. Oslo: Ministry of Education and Research.

Ministry of Education and Research (2012a). Strategi for ungdomstrinnet- Motivasjon og mestring for bedre laring. Felles satsing på klasseledelse, regning, lesing og skriving [Strategy for the lower secondary school level-Motivation and mastering for better learning. Joint effort for classroom management, mathematics, reading and writing]. Oslo, Norway: Kunnskaps- og forskningsdepartementet.

Ministry of Education and Research (2012b). Midtveisrapport Ny GIV 2012 [Report New Effort 2012]. Oslo, Norway: Kunnskaps- og forskningsdepartementet.

Ministry of Education and Research. (2017). Meld. St. 21. Larelyst - tidlig innsats og kvalitet i skolen [Motivation to learn - Early effort and quality in school]. Oslo, Norway: Kunnskaps- og forskningsdepartementet.

Moos, L. (2013). Comparing educational leadership research. Leadership and Policy in Schools, 12(3), 282-299.

Newell, S., Scarbrough, H., Robertson, M., \& Swan, J. (2002). Managing knowledge work. Palgrave.

Nygaard, C., \& Bramming, P. (2008). Learning-centered public management education. International Journal of Public Sector Management, 21(4), 400-416.

Nygaard, C., \& Holtham, C. (2008). The need for learning-centred higher education. In C. Nygaard \& C. Holtham (Eds.), Understanding learning-centred higher education (pp. 11-29). Copenhagen Business School Press.

OECD (2019). Improving school quality in Norway: The new competence development model. Implementing education policies, OECD Publishing, Paris, https://doi.org/10.1787/179d4ded-en.

Organization for Economic Cooperation and Development. (2016). What makes a school a learning organisation? A guide for policy makers, school leaders and teachers. Retrieved from http://www. oecd.org/education/school/school-learning-organisation.pdf.

Polanyi, M. (1966). The tacit dimension. Doubleday.

Polanyi, M. (1969). On body and mind. New Scholasticism, 43(2), 195-204.

Postholm, M.B., Dahl, T., Engvik, G., Fjørtoft, H., Irgens, E. J., Sandvik, L.V., Wæge, K. (2013). En gavepakke til ungdomstrinnet? En unders $\phi k e l s e$ av piloten for den nasjonale satsingen på skolebasert kompetanseutvikling. [A gift for the lower secondary level? A study of the school-based competence development in the pilot project.] Trondheim: Akademika forlag.

Postholm, M.B., Normann, A., Dahl, T., Dehlin, E., Engvik, G., Irgens, E. J. \& (2018) (Eds.). Skoleog utdanningssektoren $i$ utvikling. [The school and education field in development] Bergen: Fagbokforlaget.

Revans, R. W. (1971). Developing Effective Managers. New York: Praeger.

Revans, R. (1982). The ABC of Action Learning. Bromley: Chartwell-Bratt.

Revans, R. (1998). The ABC of action learning (2nd ed.). Lemos and Crane.

Rutter, M., Maughan, B., Mortimore, P., \& Ouston, J. (1979). 15000 hours: Secondary schools and their effects on children. Open Books.

Ryle, G. (1949). The Concept of Mind. London: Hutchinson.

Schön, D. (1983). The reflective practitioner. How professionals think in action. Temple Smith.

Sharrat, L., \& Fullan, M. (2009). Realization: The change imperative for deepening district- wide reform. Corwin Press.

Shirley, D. (2016). The new imperatives of educational change. Achievement with integrity. Routledge.

Sletten, M. A., Bakken, A., \& Haakestad, H. (2011). Ny start med Ny GIV? Kartlegging av intensivopplaringen i regi av Ny GIV-prosjektet skoleåret 2010/11 [New start with the New Effort? Study of the intensive teaching under the auspices of the New Effort project - 2010-2011 school year]. NOVA Rapport nr. 23/2011NOVA. Oslo, Norway: Norsk institutt for forskning om oppvekst, velferd og aldring.

Snow, C. E. (2014). Rigor and realism: Doing educational science in the real world. 2014 wallace foundation distinguished lecture. Educational Researcher, 44(9), 460-466.

Stoll, L., \& Kools, M. (2017). The school as a learning organisation: A review revisiting and extending a timely concept. Journal of Professional Capital and Community, 2(1), 2-17. 
Swidler, A. (1986). Culture in action: Symbols and strategies. American Sociological Review, 51, 273-286.

Townley, B., Cooper, D., \& Oakes, L. (2003). Performance measurement and the rationalization of organizations. Organization Studies, 24(7), 1045-1071.

Verger, A., Novelli, M., \& Altinyelken, H. K. (2012). Global education policy and international development: An introductory framework. In A. Verger, M. Novelli, \& H. K. Altinyelken (Eds.), Global education policy and international. Development: New agendas, issues and policies (pp. 3-32). Continuum.

Vince, R. (1998). Behind and beyond Kolb's learning cycle. Journal of Management Education, 22(3), 304-319.

Vygotsky, L. S. (1978). Mind in society: The development of higher psychological processes. Harvard University Press.

Weick, K. E. (1989). Theory construction as disciplined imagination. The Academy of Management Review, 14(4), 516-531.

Weick, K. E. (1993). Organizational redesign as improvisation. In G. P. Huber \& W. H. Glick (Eds.), Organizational change and redesign: Ideas and insights for improving performance (pp. 346-379). Oxford University Press.

Wells, G. (Ed.). (2001). Action, talk, and text: Learning and teaching through inquiry. Teachers College Press.

Wenger, E. (1998a). Communities of practice. Learning, meaning and identity. Cambridge University Press.

Weniger, E. (1953). Theorie und praxis in der erziehung [Theory and Practice in Education]. In E. Weniger (Ed.), Die Eigenständigkeit der Erziehung in Theorie und Praxis [Autonomy in education in theory and practice] (pp. 7-22). Germany: Beltz.

Wilden, A. (1987). The Rules Are No Game. London and New York: Routledge.

Worren, N. A., Moore, K., \& Elliot, R. (2002). When theories become tools: Toward a framework for pragmatic validity. Human Relations, 55(10), 1227-1250.

Yanow, D. (2004). Translating local knowledge at organizational peripheries. British Journal of Management, 15, S9-S25.

Publisher's Note Springer Nature remains neutral with regard to jurisdictional claims in published maps and institutional affiliations. 